Prepared in cooperation with the Arkansas Natural Resources Commission and the Arkansas Geological Survey

\title{
Potentiometric Surface of the Ozark Aquifer in Northern Arkansas, 2010
}

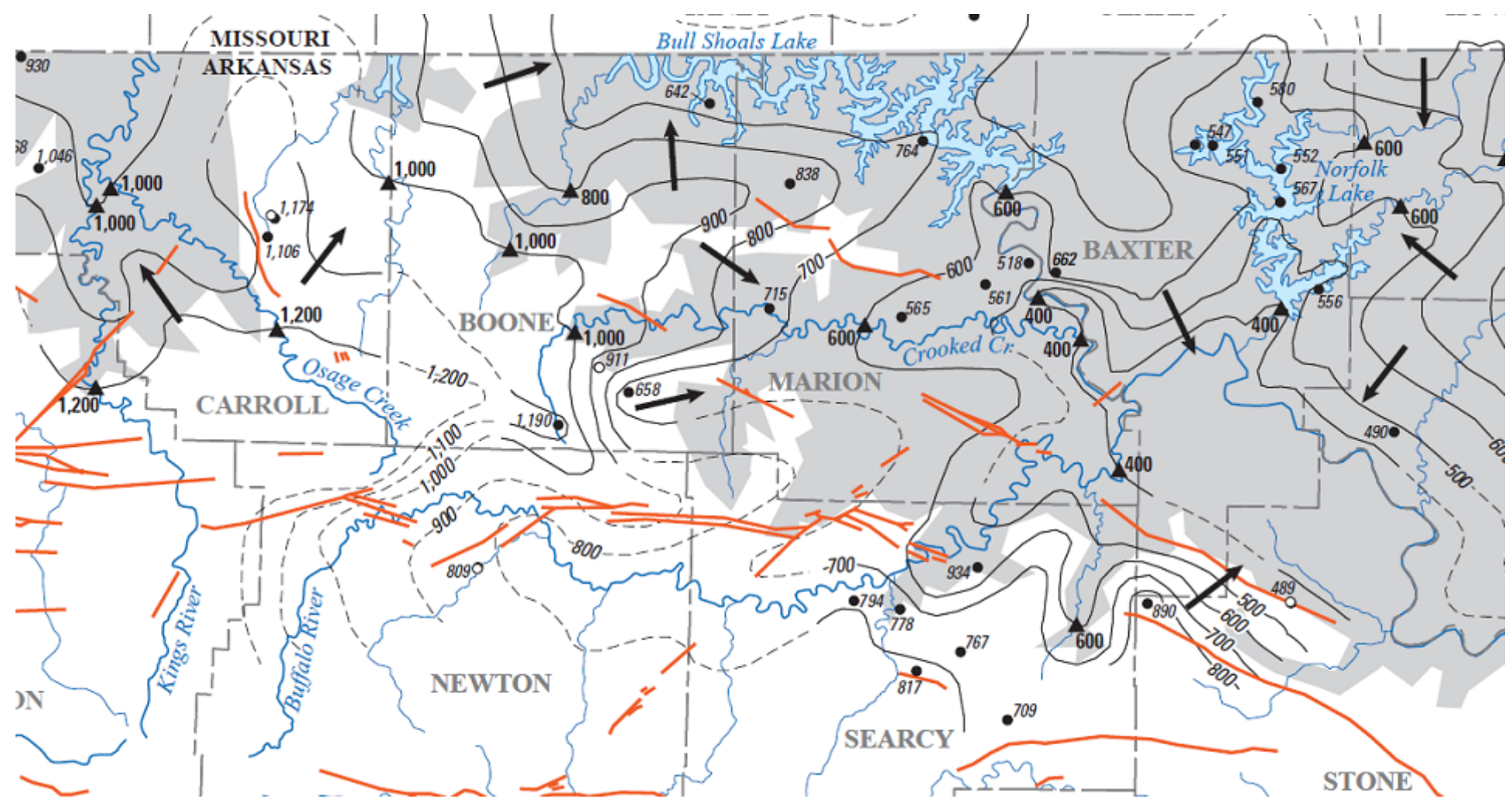

Scientific Investigations Report 2014-5013 



\section{Potentiometric Surface of the Ozark Aquifer in Northern Arkansas, 2010}

By John B. Czarnecki, Aaron L. Pugh, and Joshua M. Blackstock

Prepared in cooperation with the Arkansas Natural Resources Commission and the Arkansas Geological Survey

Scientific Investigations Report 2014-5013 


\title{
U.S. Department of the Interior \\ SALLY JEWELL, Secretary
}

\section{U.S. Geological Survey \\ Suzette M. Kimball, Acting Director}

\section{U.S. Geological Survey, Reston, Virginia: 2014}

\author{
For more information on the USGS - the Federal source for science about the Earth, its natural and living \\ resources, natural hazards, and the environment, visit http://www.usgs.gov or call 1-888-ASK-USGS. \\ For an overview of USGS information products, including maps, imagery, and publications, \\ visit http://www.usgs.gov/pubprod \\ To order this and other USGS information products, visit http://store.usgs.gov
}

Any use of trade, firm, or product names is for descriptive purposes only and does not imply endorsement by the U.S. Government.

Although this information product, for the most part, is in the public domain, it also may contain copyrighted materials as noted in the text. Permission to reproduce copyrighted items must be secured from the copyright owner.

Suggested citation:

Czarnecki, J.B., Pugh, A.L., and Blackstock, J.M., 2014, Potentiometric surface of the Ozark aquifer in northern Arkansas, 2010: U.S. Geological Survey Scientific Investigations Report 2014-5013, 16 p., 1 pl., http://dx.doi. org/10.3133/sir20145013.

ISSN 2328-0328 (online) 


\section{Contents}

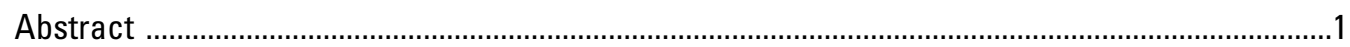

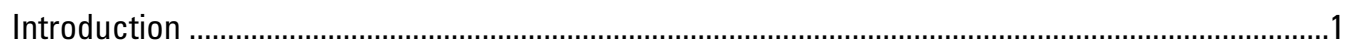

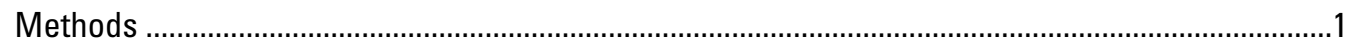

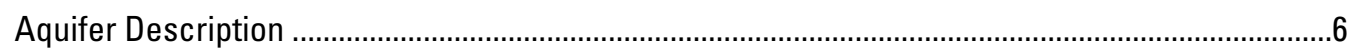

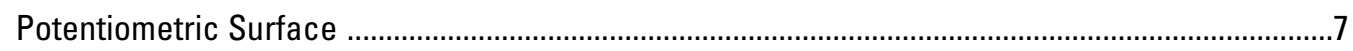

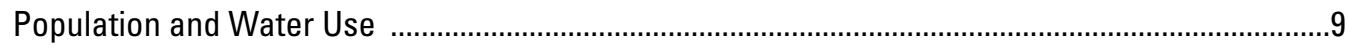

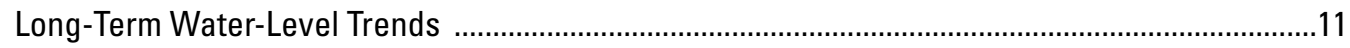

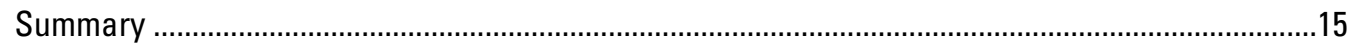

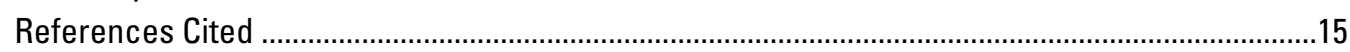

\section{Plate}

1. Map showing potentiometric surface of the Ozark aquifer in northern Arkansas, 2010

\section{Figures}

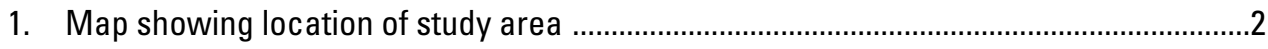

2. Map showing location of Ozark Plateaus aquifer system ..............................................6

3. Graph showing total estimated groundwater and surface-water use and population for the study area in northern Arkansas, 1960-2010 ....................................10

4. Water-level hydrographs and trends for selected wells completed in the Ozark

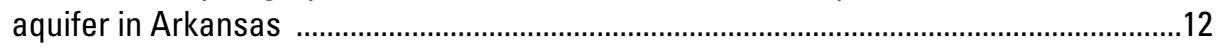

\section{Tables}

1. Information pertaining to measured wells and springs in the Ozark aquifer in northwestern Arkansas and south-central Missouri, 2010

2. Stratigraphic column with descriptions of lithologic and hydrogeologic properties of the Ozark aquifer and adjacent confining units within Arkansas ...................................8

3. Groundwater use for selected counties in northern Arkansas, 2000-10 ......................10

4. Surface-water use for selected counties in northern Arkansas, 2000-10 ....................10

5. Statistically significant water-level trends by well ......................................................15 


\section{Conversion Factors}

Inch/Pound to SI

\begin{tabular}{lcl}
\hline \multicolumn{1}{c}{ Multiply } & By & \multicolumn{1}{c}{ To obtain } \\
\hline foot (ft) & Length & meter $(\mathrm{m})$ \\
mile (mi) & 0.3048 & kilometer $(\mathrm{km})$ \\
\hline & 1.609 & \\
\hline foot per day (ft/d) & Flow rate & meter per day $(\mathrm{m} / \mathrm{d})$ \\
foot per year (ft/yr) & 0.3048 & meter per year $(\mathrm{m} / \mathrm{yr})$ \\
gallon per minute $(\mathrm{gal} / \mathrm{min})$ & 0.3048 & liter per second $(\mathrm{L} / \mathrm{s})$ \\
million gallons per day $(\mathrm{Mgal} / \mathrm{d})$ & 0.06309 & cubic meter per second $(\mathrm{m} / \mathrm{s})$ \\
\hline & 0.04381 & \\
\hline foot per mile $(\mathrm{ft} / \mathrm{mi})$ & Slope & meter per $\mathrm{kilometer}(\mathrm{m} / \mathrm{km})$ \\
\hline
\end{tabular}

Vertical coordinate information is referenced to the National Geodetic Vertical Datum of 1929 (NGVD 29).

Horizontal coordinate information is referenced to the North American Datum of 1983 (NAD 83).

Altitude, as used in this report, refers to distance above the vertical datum. 


\title{
Potentiometric Surface of the Ozark Aquifer in Northern Arkansas, 2010
}

\author{
By John B. Czarnecki, Aaron L. Pugh, and Joshua M. Blackstock
}

\section{Abstract}

The Ozark aquifer in northern Arkansas is composed of dolomite, limestone, sandstone, and shale of Late Cambrian to Middle Devonian age and ranges in thickness from approximately 1,100 feet to more than 4,000 feet. Hydrologically, the aquifer is complex, characterized by discrete and discontinuous flow components with large variations in permeability.

The potentiometric-surface map, based on 56 well and 5 spring water-level measurements made in 2010 in Arkansas and Missouri, has a maximum water-level altitude measurement of 1,174 feet in Carroll County and a minimum water-level altitude measurement of 120 feet in Randolph County. Regionally, the flow within the aquifer is to the south and southeast in the eastern and central part of the study area and to the west, northwest, and north in the western part of the study area. Water-level altitudes changed 0.5 feet or less in 31 out of 56 wells measured between 2007 and 2010.

Despite rapidly increasing population within the study area, the increase appears to have minimal effect on groundwater levels, although the effect may have been minimized by the development and use of surface-water distribution infrastructure, suggesting that most of the incoming populations are fulfilling their water needs from surface-water sources. The conversion of some users from groundwater to surface water may be allowing water levels in some wells to recover (rise) or decline at a slower rate in some areas such as in Benton, Carroll, and Washington Counties.

\section{Introduction}

The Ozark aquifer is the largest aquifer, both in area of outcrop and thickness, and the most important source of fresh groundwater in the Ozark Plateaus physiographic province, supplying water to large areas of northern Arkansas, southern Missouri, northeastern Oklahoma, and southeastern Kansas. Understanding the changes and trends in water levels is important for continued use, planning, and management of this important natural resource.
The U.S. Geological Survey (USGS), in cooperation with the Arkansas Natural Resources Commission (ANRC) and the Arkansas Geological Survey (AGS), conducted a study of groundwater-levels in the Ozark aquifer within Arkansas. The study is part of an ongoing effort to monitor groundwater levels in Arkansas' major aquifers. A substantial portion of the text used in this report is excerpted from an earlier study by Pugh (2008), one of the coauthors of the current report. The current report presents a potentiometric-surface map of the Ozark aquifer within the Ozark Plateaus of northern Arkansas (figs. 1 and 2), representing water-level conditions for the early spring 2010.

The study area includes 16 Arkansas counties lying completely or partially within the Ozark Plateaus of the Interior Highlands major physiographic division (Fenneman, 1938). The study area is generally bounded on the north by Missouri, on the west by Oklahoma, on the east by the Mississippi Alluvial Plain section, and on the south by the Ouachita province (fig. 1).

The potentiometric-surface map presented in this report was prepared from groundwater-level data and water-level data from springs flowing from the Ozark aquifer collected by the USGS during February and March 2010. Additionally, streambed altitudes in areas where the aquifer is unconfined and hydraulically connected to the surface were used as bounding (maximum groundwater level) values.

\section{Methods}

Personnel from the USGS collected water-level measurements during February and March 2010 from wells screened in and springs flowing from the Ozark aquifer. Well water-level measurements were made to the nearest 0.01 foot (ft) and were collected using steel or electric tapes from a measuring point of a known altitude. The steel and electric tapes were calibrated during January 2010. Spring water levels were considered to be the land-surface altitudes at which water from the Ozark aquifer emanated. Water-level altitudes were tabulated and compared with water-level measurements made in the same wells in 2007, from which differences in waterlevel altitudes and rates of change were calculated. 


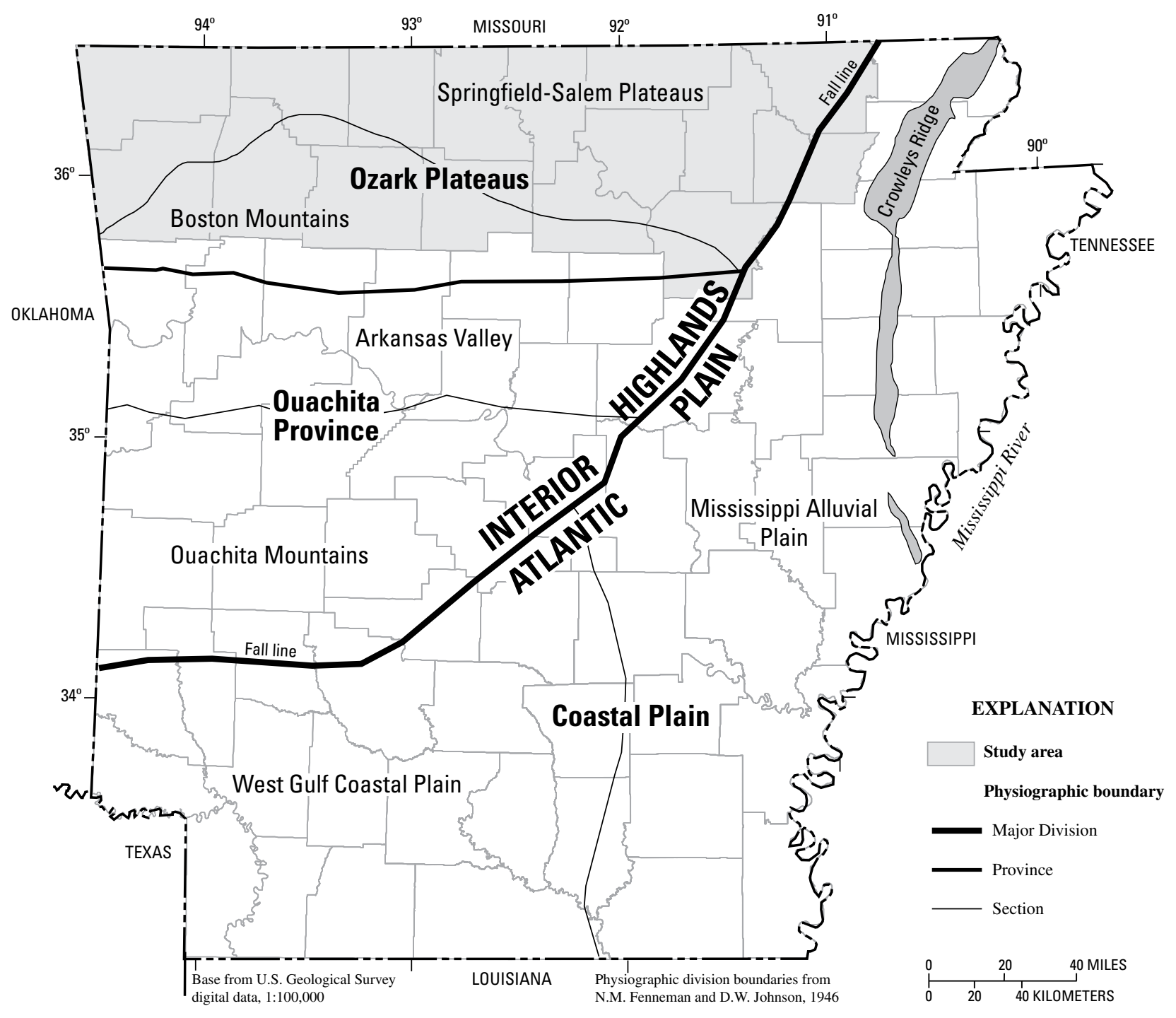

Figure 1. Location of study area.

Well and spring locations were measured using a Global Positioning System receiver to acquire the horizontal coordinate information, latitude and longitude, based on the North American Datum of 1983 (NAD 83). The latitude and longitude of the well or spring location were transferred to the appropriate 7.5-minute USGS topographic quadrangle map and the altitude (National Geodetic Vertical Datum of 1929 [NGVD 29]) was determined. Well and spring horizontal locations are accurate to $+/-10 \mathrm{ft}$, and the altitude of the land surface at this location also is accurate to $+/-10 \mathrm{ft}$.

The potentiometric surface was contoured using the 2010 water-level data from 56 wells and 5 springs (table 1). Additional bounding values from land-surface contours and stream altitudes were used where the Ozark aquifer is exposed at the surface. Where the Ozark aquifer is unconfined, landsurface contours and stream altitudes from a 1:500,000 scale topographic map of Arkansas (U.S. Geological Survey, 1990) were considered in the construction of the potentiometricsurface map to prevent contours from crossing streams at inappropriate locations and to reflect the general landsurface topography where appropriate. The potentiometricsurface map was constructed using a contour interval of $100 \mathrm{ft}$ by initially applying an automated contouring method within ArcGIS (http://www.esri.com/software/arcgis) and subsequently making manual adjustments to the contour positions. A contour interval of $100 \mathrm{ft}$ was considered the minimum value warranted by the sparseness and accuracy of the water-level altitude data. 
Table 1. Information pertaining to measured wells and springs in the Ozark aquifer in northwestern Arkansas and south-central Missouri, 2010.

[NA, not applicable; Aquifer code designations are: 364STPR, St. Peter Sandstone; 364EVRN, Everton Formation; 368PWLL, Powell Dolomite; 367CTTR, Cotter Dolomite; 368JFRC, Jefferson City Dolomite; 367RBDX, Roubidoux Formation, 367GNTR, Gunter Sandstone member of the Van Buren Formation; 367POTS, Potosi Dolomite; NGVD 29, National Geodetic Vertical Datum of 1929; Horizontal coordinate information is referenced to the North American Datum of 1983]

\begin{tabular}{|c|c|c|c|c|c|c|c|c|c|c|}
\hline $\begin{array}{l}\text { Latitude } \\
\text { (degrees, } \\
\text { minutes, } \\
\text { seconds) }\end{array}$ & $\begin{array}{l}\text { Longitude } \\
\text { (degrees, min } \\
\text { utes, seconds }\end{array}$ & $\begin{array}{l}\text { Local well } \\
\text { number }\end{array}$ & $\begin{array}{l}\text { Land-surface } \\
\text { altitude } \\
\text { (feet above } \\
\text { NGVD 29) }\end{array}$ & $\begin{array}{l}\text { Well depth } \\
\text { (feet below } \\
\text { land-surface } \\
\text { altitude) }\end{array}$ & $\begin{array}{c}\text { Aquifer code } \\
\text { of formation } \\
\text { at depth } \\
\text { of well }\end{array}$ & $\begin{array}{l}\text { Water-level } \\
\text { altitude } \\
\text { (feet above } \\
\text { NGVD 29) }\end{array}$ & $\begin{array}{c}\text { Depth to } \\
\text { water } \\
\text { (feet) }\end{array}$ & $\begin{array}{c}\text { Date of } \\
\text { measurement }\end{array}$ & $\begin{array}{l}\text { Change in } \\
\text { water-level } \\
\text { altitude } \\
\text { from } 2007 \\
\text { (feet) }\end{array}$ & $\begin{array}{l}\text { Rate of water- } \\
\text { level change } \\
\text { since } 2007 \\
\text { (feet per year) }\end{array}$ \\
\hline \multicolumn{11}{|c|}{ Arkansas } \\
\hline \multicolumn{11}{|c|}{ Baxter County } \\
\hline 361610 & 921143 & 19N11W31DAA1 & 640 & 193 & 367CTTR & 556 & 84.41 & 03-01-10 & -0.79 & -0.26 \\
\hline 361714 & 923026 & 19N14W29DBC1 & 720 & 1,625 & 367GNTR & 662 & 58.02 & $02-25-10$ & 0.37 & 0.12 \\
\hline 362114 & 921423 & 20N11W35CCA1 & 600 & 295 & 367CTTR & 567 & 33.08 & 03-01-10 & -0.84 & -0.28 \\
\hline 362309 & 921419 & 20N12W23CBA1 & 600 & 550 & 367RBDX & 552 & 47.98 & 03-01-10 & 37.48 & 12.41 \\
\hline 362431 & 921912 & 20N13W13ABD1 & 620 & 209 & 367CTTR & 551 & 69.46 & 03-01-10 & -1.83 & -0.61 \\
\hline 362435 & 922026 & 20N13W14ABC1 & 580 & 493 & 367CTTR & 547 & 32.85 & 03-01-10 & -3.82 & -1.26 \\
\hline 362700 & 921558 & 21N12W33ACB1 & 610 & 500 & 367RBDX & 580 & 30.47 & 03-01-10 & 1.00 & 0.33 \\
\hline \multicolumn{11}{|c|}{ Benton County } \\
\hline 362004 & 935553 & 19N28W11BAD1 & 1,260 & 1,030 & 367RBDX & 1,073 & 187.13 & $03-02-10$ & -1.16 & -0.39 \\
\hline 361954 & 940618 & 19N29W07DAA1 & 1,210 & 1,659 & 367GNTR & 1,066 & 144.19 & $03-02-10$ & -3.27 & -1.09 \\
\hline 362456 & 942723 & 20N33W14ACD1 & 1,185 & 1,600 & 367GNTR & 766 & 418.87 & $03-02-10$ & 0.79 & 0.26 \\
\hline 362512 & 942720 & 20N33W14DBC1 & 1,230 & 1,614 & 367GNTR & 803 & 427.12 & $03-02-10$ & 0.65 & 0.22 \\
\hline 362417 & 943607 & 20N34W21ABD1 & 1,022 & 380 & 364EVRN & 995 & 26.57 & $03-02-10$ & 0.41 & 0.14 \\
\hline 362636 & 940138 & 21N29W35DDB2 & 1,405 & 1,769 & $367 \mathrm{GNTR}$ & 1,054 & 351.46 & $03-02-10$ & -2.64 & -0.88 \\
\hline \multicolumn{11}{|c|}{ Boone County } \\
\hline 361150 & 930258 & 18N19W19BCC1 & 1,150 & 1,649 & $367 \mathrm{GNTR}$ & 911 & 239.38 & $02-25-10$ & -1.20 & -0.40 \\
\hline 361022 & 930050 & 18N19W33BBB1 & 1,300 & 2,055 & $367 \mathrm{GNTR}$ & 658 & 642.02 & $02-25-10$ & -10.02 & -3.35 \\
\hline 362703 & 925503 & 21N18W20CCD1 & 880 & 1,415 & 371POTS & 642 & 238.26 & $02-25-10$ & 1.74 & 0.58 \\
\hline \multicolumn{11}{|c|}{ Carroll County } \\
\hline 362022 & 932604 & 19N23W04BAC1 & 1,365 & 1,587 & 367RBDX & 1,174 & 190.89 & $03-02-10$ & 5.08 & 1.69 \\
\hline 361918 & 932633 & 19N23W08ADD1 & 1,355 & 2,300 & 367GNTR & 1,106 & 248.53 & $03-02-10$ & -1.22 & -0.41 \\
\hline 362340 & 934458 & 20N26W16DCA1 & 1,198 & 1,332 & 367GNTR & 1,068 & 129.55 & $03-02-10$ & 7.83 & 2.60 \\
\hline 362313 & 934253 & 20N26W23ACA1 & 1,335 & 1,713 & 371POTS & 1,046 & 288.59 & $03-02-10$ & -0.74 & -0.25 \\
\hline 362939 & 934412 & $21 \mathrm{~N} 26 \mathrm{~W} 10 \mathrm{CDC} 1$ & 1,090 & 1,122 & 367GNTR & 930 & 160.33 & $03-02-10$ & 0.81 & 0.27 \\
\hline 362921 & 934641 & 21N26W17BCC1 & 1,010 & 1,058 & 367RBDX & 979 & 30.91 & $03-02-10$ & -1.70 & -0.56 \\
\hline
\end{tabular}


Table 1. Information pertaining to measured wells and springs in the Ozark aquifer in northwestern Arkansas and south-central Missouri, 2010.-Continued

[NA, not applicable; Aquifer code designations are: 364STPR, St. Peter Sandstone; 364EVRN, Everton Formation; 368PWLL, Powell Dolomite; 367CTTR, Cotter Dolomite; 368JFRC, Jefferson City Dolomite; 367RBDX, Roubidoux Formation, 367GNTR, Gunter Sandstone member of the Van Buren Formation; 367POTS, Potosi Dolomite; NGVD 29, National Geodetic Vertical Datum of 1929; Horizontal coordinate information is referenced to the North American Datum of 1983]

\begin{tabular}{|c|c|c|c|c|c|c|c|c|c|c|}
\hline $\begin{array}{l}\text { Latitude } \\
\text { (degrees, } \\
\text { minutes, } \\
\text { seconds) }\end{array}$ & $\begin{array}{c}\text { Longitude } \\
\text { (degrees, min- } \\
\text { utes, seconds) }\end{array}$ & $\begin{array}{l}\text { Local well } \\
\text { number }\end{array}$ & $\begin{array}{l}\text { Land-surface } \\
\text { altitude } \\
\text { (feet above } \\
\text { NGVD 29) }\end{array}$ & $\begin{array}{l}\text { Well depth } \\
\text { (feet below } \\
\text { land-surface } \\
\text { altitude) }\end{array}$ & $\begin{array}{c}\text { Aquifer code } \\
\text { of formation } \\
\text { at depth } \\
\text { of well }\end{array}$ & $\begin{array}{l}\text { Water-level } \\
\text { altitude } \\
\text { (feet above } \\
\text { NGVD 29) }\end{array}$ & $\begin{array}{c}\text { Depth to } \\
\text { water } \\
\text { (feet) }\end{array}$ & $\begin{array}{c}\text { Date of } \\
\text { measurement }\end{array}$ & $\begin{array}{l}\text { Change in } \\
\text { water-level } \\
\text { altitude } \\
\text { from } 2007 \\
\text { (feet) }\end{array}$ & $\begin{array}{l}\text { Rate of water- } \\
\text { level change } \\
\text { since } 2007 \\
\text { (feet per year) }\end{array}$ \\
\hline \multicolumn{11}{|c|}{ Arkansas-Continued } \\
\hline \multicolumn{11}{|c|}{ Fulton County } \\
\hline 361707 & 913831 & 19N06W20DCA1 & 825 & 158 & 367CTTR & 734 & 90.93 & $02-24-10$ & 1.10 & 0.37 \\
\hline 361728 & 913503 & 19N06W23AAD1 & 680 & 1,630 & 367GNTR & 475 & 204.51 & $02-24-10$ & 1.37 & 0.46 \\
\hline 362210 & 914923 & 20N08W27ABD1 & 662 & 1,282 & 367GNTR & 658 & 4.18 & $02-24-10$ & 0.22 & 0.07 \\
\hline \multicolumn{11}{|c|}{ Fulton County (Spring) } \\
\hline 361908 & 913431 & 19N06W12BDAA1SP & 400 & NA & 367CTTR & 400 & 0.00 & $02-24-10$ & NA & NA \\
\hline \multicolumn{11}{|c|}{ Independence County (Spring) } \\
\hline 354949 & 913959 & 14N06W29BCC1SP & 340 & NA & 367CTTR & 340 & 0.00 & $02-23-10$ & NA & NA \\
\hline \multicolumn{11}{|c|}{ Izard County } \\
\hline 360753 & 920626 & 17N11W13AAD1 & 538 & 1,729 & 367RBDX & 490 & 48.35 & $02-24-10$ & -0.66 & -0.22 \\
\hline 361323 & 915549 & 18N09W15BCB1 & 742 & 600 & 367CTTR & 590 & 151.9 & $02-24-10$ & -59.76 & -20.01 \\
\hline \multicolumn{11}{|c|}{ Marion County } \\
\hline 361634 & 923527 & 19N15W20ACC1 & 684 & 900 & $367 \mathrm{RBDX}$ & 561 & 123.04 & $02-25-10$ & -20.44 & -6.80 \\
\hline 361442 & 924124 & 19N16W33CCB1 & 841 & 753 & 367RBDX & 565 & 275.9 & $02-25-10$ & 0.45 & 0.15 \\
\hline 361512 & 925050 & 19N18W36BDC1 & 755 & 1,392 & 367RBDX & 715 & 40.17 & $02-25-10$ & -1.35 & -0.45 \\
\hline 362452 & 923951 & 20N16W03BBA1 & 900 & 600 & 368JFRC & 764 & 135.93 & $02-25-10$ & 0.45 & 0.15 \\
\hline 362225 & 924919 & 20N17W19ABC1 & 862 & 180 & 367CTTR & 838 & 24.14 & $02-25-10$ & -3.43 & -1.14 \\
\hline \multicolumn{11}{|c|}{ Newton County } \\
\hline 360014 & 931130 & 16N21W34ABC1 & 870 & 190 & 364EVRN & 809 & 61.36 & 03-03-10 & -0.80 & -0.27 \\
\hline \multicolumn{11}{|c|}{ Randolph County } \\
\hline 361350 & 910944 & 18N02W02CAC1 & 361 & 128 & 368JFRC & 311 & 50.46 & $02-23-10$ & 2.86 & 0.96 \\
\hline 362440 & 905351 & 20N02E06AAC1 & 485 & 900 & 367RBDX & 120 & 364.96 & $02-23-10$ & 2.01 & 0.68 \\
\hline 362249 & 910959 & 20N02W15DAD1 & 440 & 170 & 367CTTR & 414 & 25.6 & $02-23-10$ & 0.61 & 0.21 \\
\hline \multicolumn{11}{|c|}{ Searcy County } \\
\hline 355126 & 923401 & 14N15W15AAC1 & 1,060 & 3,534 & 367GNTR & 709 & 350.81 & $02-26-10$ & 3.47 & 1.16 \\
\hline 355520 & 923718 & 15N15W19CDD1 & 1,100 & 550 & $364 \mathrm{EVRN}$ & 767 & 332.62 & $02-25-10$ & -6.87 & -2.30 \\
\hline 355750 & 924133 & 15N16W09BBA1 & 925 & 950 & 368PWLL & 778 & 147.41 & $02-25-10$ & 53.91 & 18.02 \\
\hline 355416 & 924025 & 15N16W34BAD1 & 1,000 & 485 & 364PLTN & 817 & 183.36 & $02-25-10$ & -0.35 & -0.12 \\
\hline 355819 & 924450 & 15N17W01CBA1 & 986 & 1,320 & 368PWLL & 794 & 192.41 & $02-26-10$ & -31.05 & -10.37 \\
\hline
\end{tabular}


Table 1. Information pertaining to measured wells and springs in the Ozark aquifer in northwestern Arkansas and south-central Missouri, 2010.-Continued

[NA, not applicable; Aquifer code designations are: 364STPR, St. Peter Sandstone; 364EVRN, Everton Formation; 368PWLL, Powell Dolomite; 367CTTR, Cotter Dolomite; 368JFRC, Jefferson City Dolomite; 367RBDX, Roubidoux Formation, 367GNTR, Gunter Sandstone member of the Van Buren Formation; 367POTS, Potosi Dolomite; NGVD 29, National Geodetic Vertical Datum of 1929; Horizontal coordinate information is referenced to the North American Datum of 1983]

\begin{tabular}{|c|c|c|c|c|c|c|c|c|c|c|}
\hline $\begin{array}{l}\text { Latitude } \\
\text { (degrees, } \\
\text { minutes, } \\
\text { seconds) }\end{array}$ & $\begin{array}{c}\text { Longitude } \\
\text { (degrees, min- } \\
\text { utes, seconds) }\end{array}$ & $\begin{array}{l}\text { Local well } \\
\text { number }\end{array}$ & $\begin{array}{l}\text { Land-surface } \\
\text { altitude } \\
\text { (feet above } \\
\text { NGVD 29) }\end{array}$ & $\begin{array}{l}\text { Well depth } \\
\text { (feet below } \\
\text { land-surface } \\
\text { altitude) }\end{array}$ & $\begin{array}{c}\text { Aquifer code } \\
\text { of formation } \\
\text { at depth } \\
\text { of well }\end{array}$ & $\begin{array}{l}\text { Water-level } \\
\text { altitude } \\
\text { (feet above } \\
\text { NGVD 29) }\end{array}$ & $\begin{array}{c}\text { Depth to } \\
\text { water } \\
\text { (feet) }\end{array}$ & $\begin{array}{c}\text { Date of } \\
\text { measurement }\end{array}$ & $\begin{array}{l}\text { Change in } \\
\text { water-level } \\
\text { altitude } \\
\text { from } 2007 \\
\text { (feet) }\end{array}$ & $\begin{array}{l}\text { Rate of water- } \\
\text { level change } \\
\text { since } 2007 \\
\text { (feet per year) }\end{array}$ \\
\hline \multicolumn{11}{|c|}{ Arkansas-Continued } \\
\hline \multicolumn{11}{|c|}{ Sharp County } \\
\hline 355812 & 913318 & 15N05W06DDD1 & 645 & 482 & 364EVRN & 540 & 105.41 & $02-23-10$ & -0.68 & -0.23 \\
\hline 360233 & 913338 & 16N05W06DCC1 & 450 & 1,110 & 367RBDX & 405 & 45.43 & $02-23-10$ & -1.89 & -0.64 \\
\hline 360023 & 913654 & 16N06W27ACC1 & 650 & 1,000 & 367CTTR & 554 & 96.37 & $02-23-10$ & -0.54 & -0.18 \\
\hline 360818 & 912804 & 17N05W12BDC1 & 417 & 425 & 367CTTR & 355 & 62.07 & $02-23-10$ & -1.65 & -0.56 \\
\hline 360604 & 913854 & 17N06W29ABC1 & 525 & 900 & 367CTTR & 440 & 84.74 & $02-23-10$ & -1.14 & -0.38 \\
\hline 361325 & 913638 & 18N06W10CBC1 & 625 & 1,525 & $367 \mathrm{GNTR}$ & 497 & 127.77 & $02-23-10$ & 14.02 & 4.72 \\
\hline 361813 & 912337 & 19N04W15BAA1 & 584 & 611 & $367 \mathrm{RBDX}$ & 531 & 52.58 & $02-23-10$ & 1.05 & 0.35 \\
\hline \multicolumn{11}{|c|}{ Sharp County (Springs) } \\
\hline 360228 & 913211 & 16N05W17AABA1SP & 495 & NA & 364STPR & 495 & 0.00 & $02-24-10$ & NA & NA \\
\hline 360325 & 913631 & 16N06W10AAA1SP & 435 & NA & 364EVRN & 435 & 0.00 & $02-24-10$ & NA & NA \\
\hline 360325 & 913648 & 16N06W10ABBA1SP & 455 & NA & 364EVRN & 455 & 0.00 & $02-24-10$ & NA & NA \\
\hline \multicolumn{11}{|c|}{ Stone County } \\
\hline 355805 & 921352 & 15N12W02BCA1 & 980 & 3,420 & $367 \mathrm{GNTR}$ & 489 & 490.61 & $02-24-10$ & 1.48 & 0.50 \\
\hline 355806 & 922402 & 15N13W06AC1 & 1,123 & 3,105 & 367RBDX & 890 & 232.7 & $02-24-10$ & -0.60 & -0.20 \\
\hline \multicolumn{11}{|c|}{ Washington County } \\
\hline 355903 & 941807 & 15N31W17BBD1 & 1,195 & 2,097 & 367GNTR & 1,156 & 38.59 & 03-03-10 & 0.19 & 0.06 \\
\hline 355652 & 941858 & 15N31W30CAD1 & 1,165 & 2,485 & 367GNTR & 1,144 & 20.64 & $03-03-10$ & -0.83 & -0.28 \\
\hline 360509 & 942242 & 16N32W09ABD1 & 1,135 & 1,815 & $367 \mathrm{GNTR}$ & 988 & 146.56 & 03-03-10 & -0.43 & -0.14 \\
\hline \multicolumn{11}{|c|}{ Missouri } \\
\hline \multicolumn{11}{|c|}{ Ozark County } \\
\hline 363206 & 923609 & 21N15W03BAB1 & 805 & 550 & $367 \mathrm{GSCD}$ & 663 & 142.38 & 03-01-10 & -2.03 & -0.67 \\
\hline \multicolumn{11}{|c|}{ Taney County } \\
\hline 363640 & 930554 & 23N20W27CCC1 & 763 & 350 & $367 \mathrm{RBDX}$ & 666 & 97.31 & $03-02-10$ & -5.59 & -1.87 \\
\hline 363603 & 930601 & 23N20W33ADD1 & 705 & 410 & $367 \mathrm{RBDX}$ & 654 & 50.61 & $03-02-10$ & -3.19 & -1.05 \\
\hline
\end{tabular}


Hydrographs with least squares linear regression trend lines were constructed for wells open to the Ozark aquifer with a minimum of 30 years of groundwater-level measurements. Least squares linear regression trend lines are a mathematical method of organizing data by plotting the data graphically and drawing a best fit straight trend line through the data by minimizing the sum of the squares of the offsets (residuals) (McCuen, 1985). Linear regression analysis was done using the regression function in Microsoft Excel on scatter point datasets, which is different than the method used in Pugh (2008). The equation of the trend line is represented by:

$$
y=m x+b
$$

where

$$
\begin{gathered}
y \quad \text { is the dependent variable (water-level altitude, } \\
\text { in feet) } \\
\text { is the slope of the trend line (annual rise or } \\
\text { decline in water level, in feet per year), } \\
\text { is the independent variable (time, in years), } \\
\text { and } \\
\text { is the } y \text { intercept value (value of } y \text { at } x=0) .
\end{gathered}
$$

Coefficients of variation $\left(\mathrm{R}^{2}\right)$ were calculated for each trend line to indicate statistical significance. Values less than 0.5 were considered to indicate a trend that was not statistically significant.

\section{Aquifer Description}

The Ozark Plateaus aquifer system (fig. 2) in and adjacent to the Ozark Plateaus is divided into five hydrogeologic units based on relative rock permeability and well yields. These hydrogeologic units crop out in a concentric pattern centered on the St. Francois Mountains of southeastern Missouri and dip to the southeast and south in northeastern Arkansas and to the south and southwest in north-central and northwestern Arkansas. The boundaries between these hydrogeologic units do not always conform to geologic time divisions or formation boundaries but were chosen to delineate groups of rocks having similar hydrologic properties. These hydrogeologic units consist of rocks that range in age from Cambrian to Devonian and are the St. Francois aquifer, St. Francois confining unit, Ozark aquifer, Ozark confining unit, and Springfield Plateau aquifer (Imes and Emmett, 1994). The St. Francois aquifer and St. Francois confining unit underlie the Ozark aquifer. The Ozark confining unit overlies the Ozark aquifer and the Springfield Plateau aquifer overlies the Ozark confining unit.

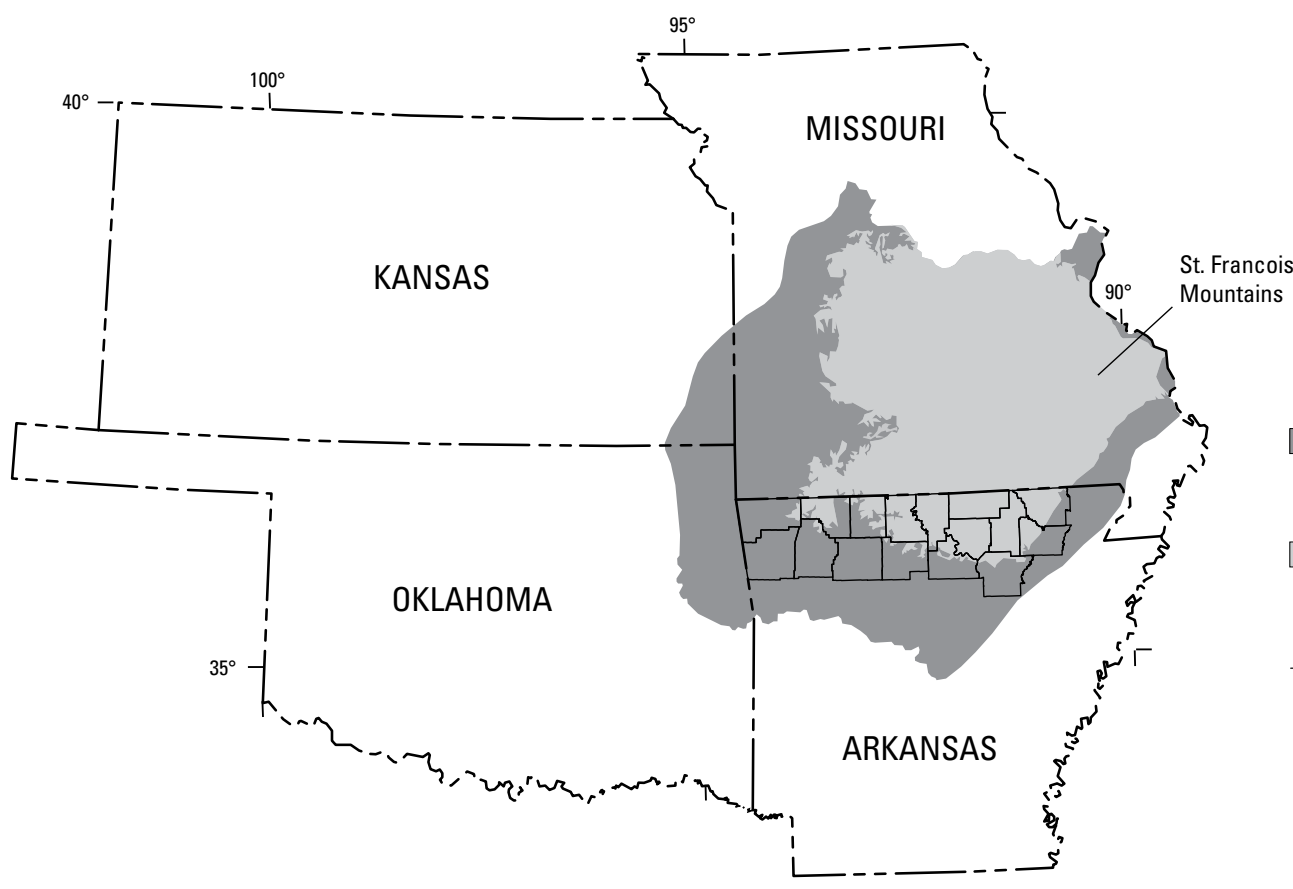

EXPLANATION

Approximate area of the Ozark Plateaus aquifer system, where overlain by younger units

Approximate area of the Ozark Plateaus aquifer system, where the Ozark aquifer crops out

- Counties in Arkansas representing the study area

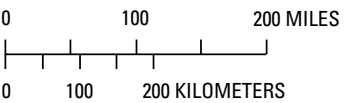

Figure 2. Location of Ozark Plateaus aquifer system. 
The Ozark aquifer is underlain by the St. Francois confining unit (the uppermost geologic unit of which is the Doe Run Dolomite; table 2). The Ozark aquifer is exposed in much of southern and central Missouri and north-central Arkansas (fig. 2) where uplift of the Ozark Dome and erosion of younger rocks has formed a deeply dissected, rugged topography that is the primary recharge area of the aquifer. The aquifer is overlain by the Ozark confining unit mainly in the southern and western part of the study area (fig. 2; table 2). Within the Mississippi Alluvial Plain, east and southeast of the outcrop area (fig. 1), thick deposits of Cretaceous-, Tertiary-, and Quaternary-age sediments unconformably overlay the Ordovician-age rocks of the Ozark aquifer. Within this part of the Mississippi Alluvial Plain, major rivers receive substantial discharge from the adjacent Ozark aquifer (Mesko and Imes, 1995).

Groundwater flow and hydraulic properties within the Ozark aquifer are affected by spatial variations in hydrologicunit thickness, fault locations and hydraulic properties, lithologic type, and degree of cementation. Values of primary porosity and permeability are small for most rock units of the Ozark aquifer, although secondary permeability resulting from fracturing, bedding planes, and dissolution of the carbonate rocks is spatially variable and ranges from moderate to large (Adamski, 1996). Hydraulic conductivity ranges from $1 \times 10^{-3}$ feet per day (ft/d) to more than $1 \times 10^{2} \mathrm{ft} / \mathrm{d}$ (Imes and Emmett, 1994). The principal recharge area for the Ozark aquifer is in central and south-central Missouri and north-central Arkansas, where the aquifer is hydraulically connected to the surface and the potentiometric surface mimics the land-surface topography.

Most wells completed in the Ozark aquifer yield between 50 and 100 gallons per minute (gal $/ \mathrm{min}$ ) although some wells may yield as much as $600 \mathrm{gal} / \mathrm{min}$ (Imes and Emmett, 1994; Adamski and others, 1995). The thick, extensive, and productive Ozark aquifer is the principal source of groundwater in northern Arkansas, except for northwestern Arkansas, which derives most of its water from Beaver Lake (Beaver Lake Water District, 2013), with the most important water-producing strata being the sandstones of the Roubidoux Formation and the Gunter Sandstone Member of the Van Buren Formation (table 2). Wells completed in the Roubidoux Formation yield an average of $60 \mathrm{gal} / \mathrm{min}$ (Adamski and others, 1995). The Gunter Sandstone Member is the principal water-yielding zone within the Ozark aquifer; wells that penetrate the unit commonly yield from 150 to $300 \mathrm{gal} / \mathrm{min}$, and some wells yield as much as $500 \mathrm{gal} / \mathrm{min}$. Although the Potosi Dolomite of Cambrian age is the principal source of water for municipalities in the Salem Plateau area of Missouri, in northern Arkansas, the water-yielding characteristics of this formation are poorly understood because it is located at great depths making it economically unsuited for development as a water resource. Minor water-yielding zones of the Ozark aquifer are contained within the Jefferson City, the Cotter, and the Powell Dolomites; the upper part of the Everton
Formation; the St. Peter Sandstone; and the St. Clair, the Lafferty, and the Clifty Limestones (table 2). Yields from these units range from 50 to $80 \mathrm{gal} / \mathrm{min}$ (Renken, 1998).

Beneath the Mississippi Alluvial Plain (fig. 1), the rocks composing the Ozark aquifer dip at about 45 feet per mile (ft/mi) to the southeast. In the northern part of the study area, the regional dip is about $26 \mathrm{ft} / \mathrm{mi}$ southward, increasing to $175 \mathrm{ft} / \mathrm{mi}$ or more at the southern boundary of the Ozark Plateaus (Imes, 1990). The depth of the Ozark aquifer increases to more than $4,000 \mathrm{ft}$ below land surface in the southern part of the study area. In this area, water quality is affected by increasing amounts of dissolved solids, fluoride, sulfide, and radium as water moves downdip, away from recharge areas (Imes and Emmett, 1994). The combination of greater depth and poorer water quality limits the viability of the Ozark aquifer as an economic source of water in the southernmost part of the study area.

\section{Potentiometric Surface}

Water-level measurements (table 1) were used to construct an updated potentiometric-surface map to the one reported by Pugh (2008). The updated potentiometric-surface map is provided in plate 1 of this report. The potentiometricsurface map indicates the altitude to which water would stand in wells completed in the Ozark aquifer and is intended to show the general configuration of the potentiometric surface. The Ozark aquifer covers a large area in Arkansas and has variable thickness and hydrologic properties that can affect water-level altitudes and hydraulic gradients. Water-level data distribution is sparse in some areas. Because of these various factors, the potentiometric-surface map should not be used to estimate exact water-level altitude or depth to water at any given location.

With few exceptions, the potentiometric-surface contours and general direction of groundwater flow are very similar to Pugh (2008). In most of the study area, the general level and shape of the potentiometric surface has changed little as mapped in previously published USGS reports in 1995 (Pugh, 1998), 2001 (Schrader, 2001), and 2004 (Schrader, 2005). Potentiometric-surface differences can be attributed to differences in hydrologic stresses (withdrawals related to changing population, differences in withdrawals for agricultural uses, or withdrawal conditions just prior to a water-level measurement) or data-collection and mapconstruction methods (time of year or number of water-level measurements and locations of water-level measurements used to construct maps representing different years). Local highs within the potentiometric surface occur along topographically high ridges, such as in Fulton and Izard Counties, which appear as 'fingers' along the 700 -ft contour. Lows within the potentiometric surface occur at topographically low areas, such as along the White River, which forms the border between Stone and Izard Counties. 
Table 2. Stratigraphic column with descriptions of lithologic and hydrogeologic properties of the Ozark aquifer and adjacent confining units within Arkansas (modified from Lamonds, 1972; Imes, 1990; Imes and Smith, 1990).

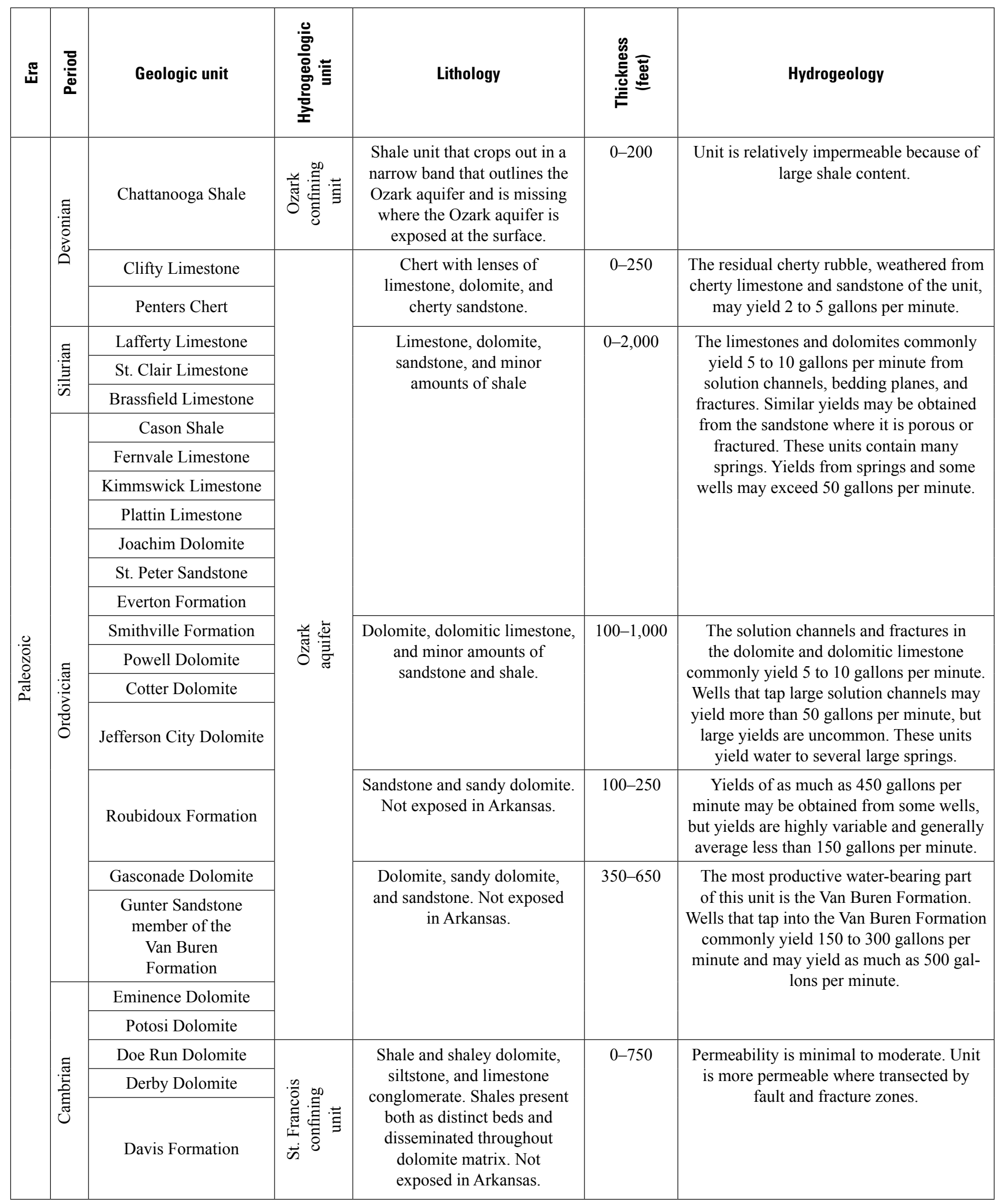


The 2010 water-level data indicate the highest measured water-level altitude is 1,174 ft above NGVD 29 in Carroll County. Water-level altitudes of less than $400 \mathrm{ft}$ above NGVD 29 are mapped along the eastern and southeastern parts of the study area in Independence, Lawrence, Randolph, and Sharp Counties. The lowest measured water level of $120 \mathrm{ft}$ above NGVD of 1929 was measured in eastern Randolph County. Of the 56 water-level altitudes measured in 2010 , 24 rose and 32 declined compared to measurements made in 2007 in the same wells (table 1). The majority of wells measured (31) had rates of change with absolute values of less than $0.5 \mathrm{ft} / \mathrm{yr}$. Water-level rises of $0.5 \mathrm{ft} / \mathrm{yr}$ or less occurred in 15 wells; declines of $0.5 \mathrm{ft} / \mathrm{yr}$ or less occurred in 16 wells. The largest rise occurred in well 15N16W09BBA1 in Searcy County with an increase in water-level altitude of $53.91 \mathrm{ft}$, or a rate of rise of $18.02 \mathrm{ft} / \mathrm{yr}$ between 2007 and 2010. The largest decline occurred in well 18N09W15BCB1 in Izard County with a decrease in water-level altitude of $-59.76 \mathrm{ft}$, or a rate of decline of $-20.01 \mathrm{ft} / \mathrm{yr}$ between 2007 and 2010 .

Potentiometric-surface contours in Stone County differ from those presented in Pugh (2008). Pugh (2008) erroneously transposed two water-level altitudes in Stone County (631 and $748 \mathrm{ft}$ ) that were used in the construction of the 2007 potentiometric-surface map.

Faults within the study area likely affect water levels within the Ozark aquifer. However, faults shown on plate 1 were not used to adjust contour line positions because of the sparseness of water-level measurements. Fault traces shown represent major faults mapped by Haley and others (1993).

The potentiometric-surface map depicts the general direction of groundwater flow within the Ozark aquifer, with horizontal groundwater movement perpendicular to the potentiometric-surface contours or the direction of the horizontal hydraulic gradient. Generalized groundwater-flow directions shown on plate 1differ little from those of Pugh (2008) or the predevelopment potentiometric surface by Imes and Emmett (1994). An exception to this occurs in western Stone County, resulting from a correction to the assignment of water-level altitudes that were erroneously transposed between two measuring points in Pugh (2008). Regionally, the flow within the aquifer is to the south and southeast in the eastern and central part of the study area and to the west, northwest, and north in the western part of the study area.

The extent of the potentiometric-surface map presented on plate 1 covers approximately one-half of the area of the Ozark Plateaus in Arkansas (fig. 1). In the southern part of the study area, the aquifer is not a viable source of water because of great depths and poor water quality (Imes and Emmett, 1994). Few water wells have been constructed in this part of the study area, consequently, no data are available for contouring purposes.

\section{Population and Water Use}

The population of the 16 counties in northern Arkansas that compose the study area has increased steadily since 1960 (fig. 3). From 1960 through 2010 the population in the State of Arkansas has increased 63 percent while counties within the study area increased 201 percent. The largest increase in population was in the counties bordering Missouri and Oklahoma including Benton (510 percent), Baxter (318 percent), Washington (264 percent), Marion (176 percent), Sharp (173 percent), Carroll (143 percent), and Boone (129 percent). Lawrence and Searcy Counties experienced the smallest increases in population at 1 percent each (U.S. Census Bureau, 2013).

Estimated surface-water use fluctuated substantially during the period 1960-2010 (fig. 3). A large increase in estimated surface-water use between 1985 and 1990 is attributed mainly to changes in surface-water use data collection methods. Surface-water use associated with thermoelectric power generation at the Flint Creek Power Plant in Benton County was subtracted from the total surface-water use beginning in 1990. The Beaver Water District became operational in 1973 providing approximately 40 million gallons per day (Mgal/d) to municipal publicsupply systems in Benton, Carroll, and Washington Counties (Pugh, 2008; Beaver Water District, 2013). Beaver Water District and other similar facilities across the State began to report surface-water use in 1990 when the ANRC started collecting water-use data from these facilities.

Estimated total groundwater use for the Ozark aquifer in Arkansas has varied moderately for the period from 1960 through 2010, while estimated total surface-water use has increased dramatically for the same time period for the study area (fig. 3). Estimated groundwater use from the Ozark aquifer in Arkansas peaked in 1975 at $38.29 \mathrm{Mgal} / \mathrm{d}$ and subsequently declined to $22.27 \mathrm{Mgal} / \mathrm{d}$ in 2010 . Estimated surface-water use (less thermoelectric power usage) rose to $251.17 \mathrm{Mgal} / \mathrm{d}$ in 2010 (fig. 3; Terrance W. Holland, U.S. Geological Survey, written commun., 2013). Overall, groundwater use was a much smaller amount compared to that reported for surface-water use from 1990 to 2010 (fig. 3). Groundwater-use data from 2000 to 2010 are listed by county in table 3 ; surface-water use data are listed in table 4 . Of the 16 counties in the study area, 11 experienced a decrease in groundwater use between 2005 and 2010, 4 counties experienced an increase, and 1 was unchanged (table 3). Benton and Searcy Counties had substantially more groundwater use between 2005 and 2010, with Benton County reporting the largest amount of groundwater use $(5.68 \mathrm{Mgal} / \mathrm{d}$ in 2010 or a 98-percent increase over 2005 rates). 


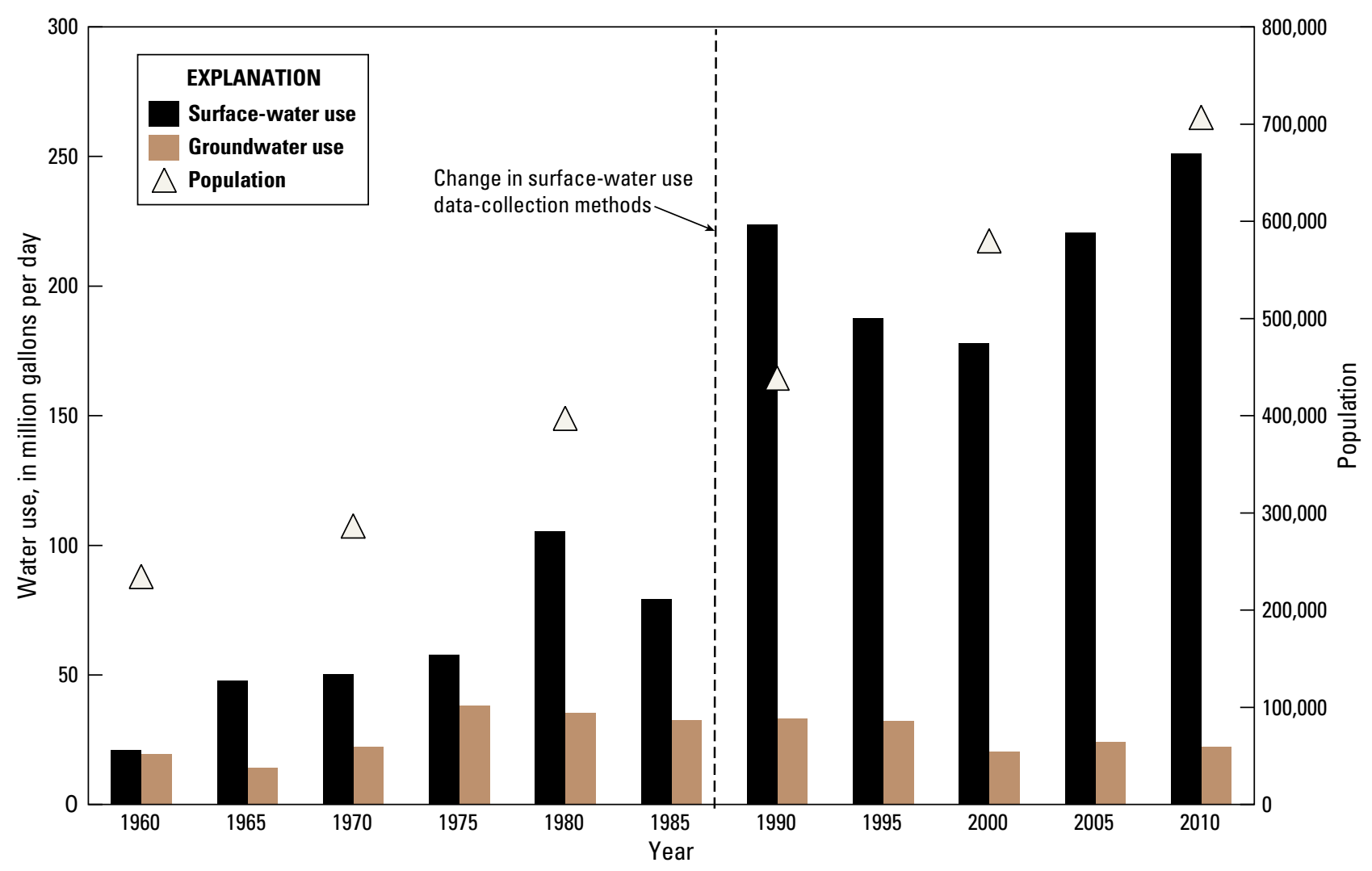

Figure 3. Total estimated groundwater and surface-water use and population for the study area in northern Arkansas, $1960-2010$.

Table 3. Groundwater use for selected counties in northern Arkansas, 2000-10.

[Modified from Holland (2004, 2007). All values in million gallons per day; 2010 values are provisional (Terrance W. Holland, U.S. Geological Survey, written commun., 2013)]

\begin{tabular}{lrrrr}
\hline \multicolumn{1}{c}{ County } & \multicolumn{3}{c}{ Year } \\
\cline { 2 - 5 } & $\mathbf{2 0 0 0}$ & $\mathbf{2 0 0 5}$ & $\mathbf{2 0 1 0}$ & $\begin{array}{c}\text { Change from } \\
\text { 2005 to 2010 } \\
\text { (percent) }\end{array}$ \\
\hline Baxter & 1.95 & 1.95 & 1.37 & -30 \\
Benton & 2.49 & 2.87 & 5.68 & 98 \\
Boone & 1.88 & 1.91 & 1.79 & -6 \\
Carroll & 2.19 & 2.87 & 2.09 & -27 \\
Fulton & 0.99 & 1.96 & 1.89 & -4 \\
Independence & 0.00 & 0.00 & 0.00 & 0 \\
Izard & 2.29 & 1.79 & 1.30 & -27 \\
Lawrence & 0.08 & 0.93 & 0.62 & -33 \\
Madison & 1.58 & 1.15 & 0.93 & -19 \\
Marion & 0.26 & 0.83 & 0.84 & 1 \\
Newton & 0.91 & 1.17 & 1.15 & -2 \\
Randolph & 0.24 & 0.25 & 0.09 & -64 \\
Searcy & 0.84 & 0.29 & 1.54 & 431 \\
Sharp & 1.63 & 4.23 & 1.28 & -70 \\
Stone & 0.68 & 0.60 & 0.61 & 2 \\
Washington & 2.51 & 1.35 & 1.09 & -19 \\
\hline \multicolumn{1}{c}{ Totals } & 20.52 & 24.15 & 22.27 & -8 \\
\hline
\end{tabular}

Table 4. Surface-water use for selected counties in northern Arkansas, 2000-10.

[Modified from Holland $(2004,2007)$. All values in million gallons per day; 2010 values are provisional (Terrance W. Holland, U.S. Geological Survey, written commun., 2013)]

\begin{tabular}{lrrrr}
\hline \multicolumn{1}{c}{ County } & \multicolumn{3}{c}{ Year } \\
\cline { 2 - 5 } & $\mathbf{2 0 0 0}$ & $\mathbf{2 0 0 5}$ & $\mathbf{2 0 1 0}$ & $\begin{array}{c}\text { Change from } \\
\text { 2005 to 2010 } \\
\text { (percent) }\end{array}$ \\
\hline Baxter & 4.35 & 3.88 & 3.47 & -11 \\
Benton & 19.52 & 60.21 & 63.04 & 5 \\
Boone & 3.49 & 1.19 & 1.00 & -16 \\
Carroll & 5.41 & 8.72 & 8.94 & 3 \\
Fulton & 1.54 & 0.48 & 0.49 & 2 \\
Independence & 44.34 & 62.74 & 98.59 & 57 \\
Izard & 0.56 & 3.22 & 3.34 & 4 \\
Lawrence & 30.06 & 32.83 & 18.75 & -43 \\
Madison & 2.20 & 0.98 & 0.84 & -14 \\
Marion & 3.29 & 1.21 & 1.19 & -2 \\
Newton & 0.37 & 0.23 & 0.21 & -9 \\
Randolph & 30.62 & 38.88 & 44.75 & 15 \\
Searcy & 0.90 & 0.70 & 0.27 & -61 \\
Sharp & 1.24 & 0.98 & 2.11 & 115 \\
Stone & 1.08 & 1.84 & 2.12 & 15 \\
Washington & 29.16 & 2.50 & 2.06 & -18 \\
\hline$\quad$ Totals & 178.13 & 220.59 & 251.17 & 14 \\
\hline
\end{tabular}


The large increase in population within the study area is not reflected by a similar increase in groundwater use from the Ozark aquifer. Although the population for the study area increased by 201 percent from 1960 to 2010, the groundwater use from the Ozark aquifer increased by only 13 percent for the same time period. The relatively small increase in groundwater use, when compared to the increase in population, is attributed to the completion of Beaver Lake in 1966, and the subsequent creation of Beaver Water Districts and other surface-water supply systems meeting the water needs of the rapidly increasing population. Surface-water usage (less thermoelectric power usage) increased 1,081 percent between 1960 and 2010 (fig. 3). For the period 2005 to 2010 , surface-water usage increased by 14 percent, compared to a decrease in groundwater usage of 8 percent (tables 3 and 4).

\section{Long-Term Water-Level Trends}

Hydrographs with regression trend lines were constructed for wells open to the Ozark aquifer with at least 30 years of periodically measured groundwater levels. Twenty-four hydrographs from 12 wells are presented in figure 4 and were selected to provide a relatively even geographic distribution across the study area. Hydrographs (fig. 4) are arranged in alphabetical order by county name. The minimum 30 -year period of record was used to evaluate water-level trends in wells that were minimally affected by localized pumping. Trend lines, using least squares linear regression analysis, were calculated for two time periods (1967-87 and 19872010) to determine the rates of water-level change in each well for each time period. The year 1987 was selected as the break point in trend lines, in part, because it is about the time that estimated surface-water use increased dramatically (fig. 3).

Pugh (2008) divided water-level trends in the Ozark aquifer into two 20-year periods (1967-87 and 1987-2007) to assess the change in water-level trends. Of the 56 wells measured in the Arkansas part of the Ozark aquifer in 2010,
22 of the wells have long-term records of 30 or more years. Out of the 16 counties in the study area, 10 counties have one or more wells with long-term records. Carroll, Sharp, and Washington Counties have three or more wells with long-term records. Baxter, Independence, Lawrence, Madison, Randolph, and Searcy Counties have no wells with long-term records.

The slopes of the trend lines are an estimate of the rate of change in water levels for each time period. The fit of the trend lines to each dataset are reflected by the values of the coefficients of variation $\left(R^{2}\right)$. $R^{2}$ values can vary between 0 and 1 . An $\mathrm{R}^{2}$ value of 0 may reflect a poor fit of the trend line or the absence of any slope to the trend line; an $\mathrm{R}^{2}$ value of 1 indicates a perfect fit of the trend line to the data. Trend lines and $\mathrm{R}^{2}$ values are shown on each hydrograph in figure 4 . A statistically significant trend was considered in this study to have an $\mathrm{R}^{2}$ value greater than 0.5. Pugh's (2008) analysis of trend lines showed that it was difficult to detect statistically significant trends in many of the hydrographs. Countywide assessments of water-level trends are hampered by lack of sufficient wells with statistically significant water-level trends. Five wells that had water-level trends that were considered statistically significant are listed in table 5 . Benton, Boone, Sharp, and Washington Counties had one well each that showed declining water- level trends; Carroll County had one well with a rising water-level trend.

An examination of water-use and population data and hydrograph trends over time provides some insight into changing water levels in the Ozark aquifer. The rapidly increasing population within the study area appears to have some effect on groundwater levels. However, the effect may have been minimized by the development and use of surfacewater distribution infrastructure, suggesting that most of the incoming populations are fulfilling their water needs from surface-water sources. The conversion of some users from groundwater to surface water may be allowing water levels in wells to recover (rise) or decline at a slower rate, such as in Benton, Carroll, and Washington Counties. Water levels in wells continue to decline at some locations where the users have not converted to surface water, such as in Sharp County. 

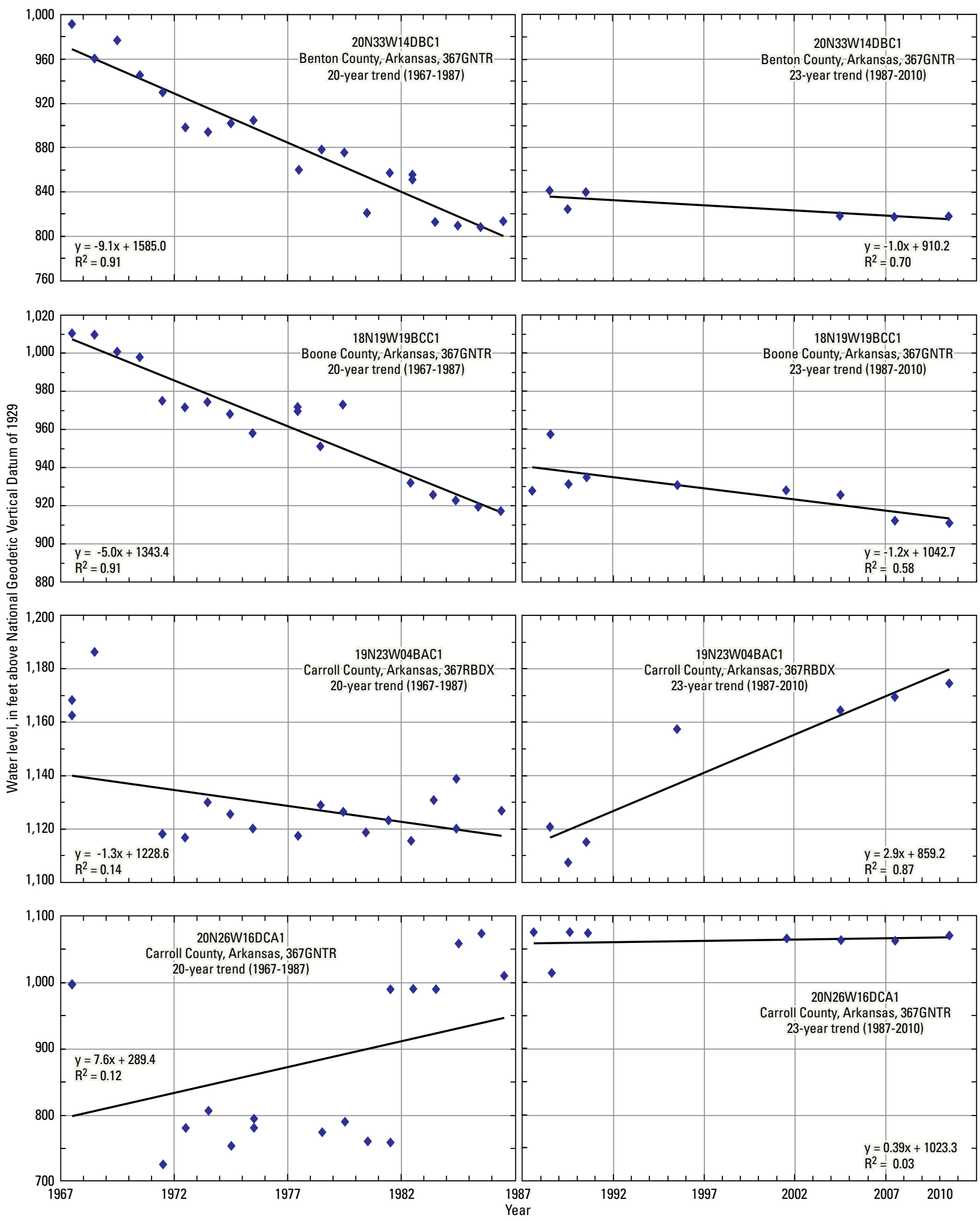

Note: $y$ is water-level altitude, in feet;

$\mathrm{x}$ is time, in years;

$R_{2}$ is the coefficient of variation, indicating statistical significance of the line of best fit

Figure 4. Water-level hydrographs and trends for selected wells completed in the Ozark aquifer in Arkansas. 

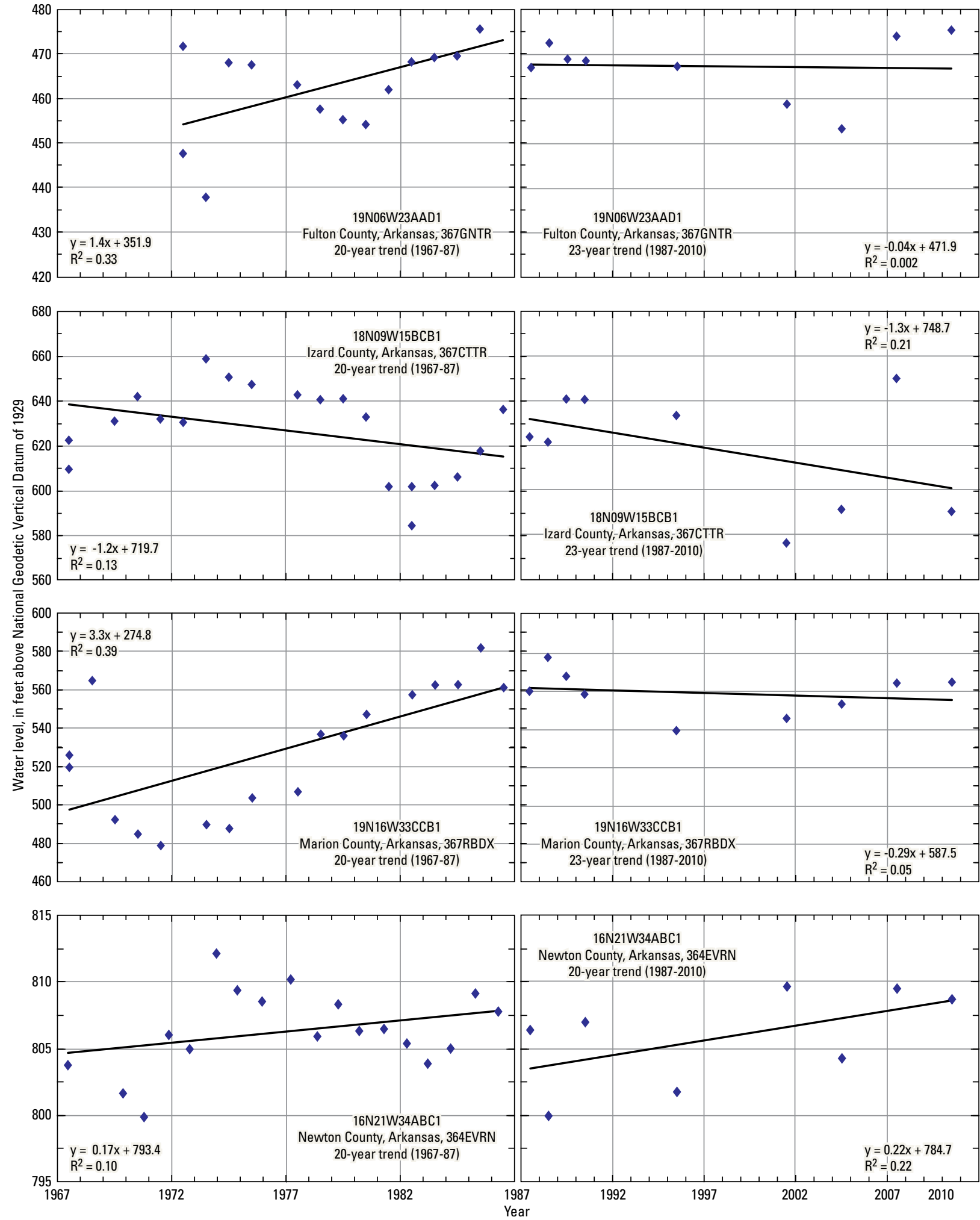

Note: $y$ is water-level altitude, in feet;

$\mathrm{x}$ is time, in years;

$R_{2}$ is the coefficient of variation, indicating statistical significance of the line of best fit

Figure 4. Water-level hydrographs and trends for selected wells completed in the Ozark aquifer in Arkansas.-Continued 

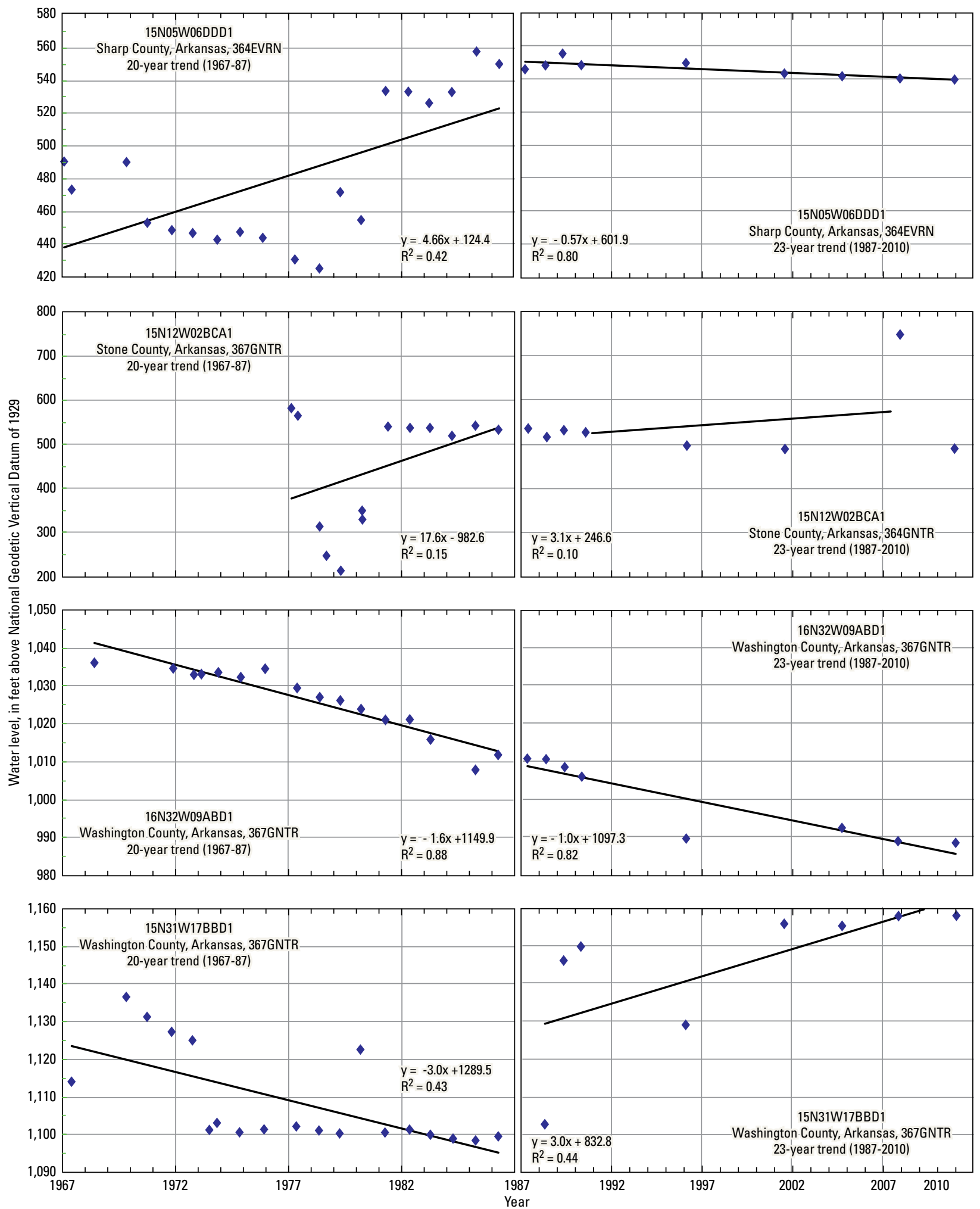

Note: $y$ is water-level altitude, in feet

$\mathrm{x}$ is time, in years;

$R_{2}$ is the coefficient of variation, indicating statistical significance of the line of best fit

Figure 4. Water-level hydrographs and trends for selected wells completed in the Ozark aquifer in Arkansas.-Continued 
Table 5. Statistically significant water-level trends by well.

[A statistically significant water-level trend has a coefficient of variation $\left(\mathrm{R}^{2}\right)$ value greater than $0.5 ;-$, no value]

\begin{tabular}{lccc}
\hline \multirow{1}{*}{ County } & Well & \multicolumn{2}{c}{$\begin{array}{c}\text { Water-level rate of change } \\
\text { (feet/year) }\end{array}$} \\
\cline { 3 - 4 } & & $\mathbf{1 9 6 7}$ to 1987 & $\mathbf{1 9 8 7}$ to $\mathbf{2 0 1 0}$ \\
\hline Benton & 20N33W14DBC1 & -9.1 & -1.0 \\
Boone & 18N19W19BCC1 & -5.0 & -1.2 \\
Carroll & 19N23W04BAC1 & - & 2.9 \\
Sharp & 15N05W06DDD1 & - & -0.57 \\
Washington & 16N32W09ABD1 & -1.6 & -1.0 \\
\hline
\end{tabular}

\section{Summary}

During February and March 2010, groundwater levels from 56 wells and 5 springs in the Ozark aquifer in northern Arkansas and southern Missouri were measured by the U.S. Geological Survey in cooperation with the Arkansas Natural Resources Commission and the Arkansas Geological Survey. A potentiometric-surface map of the Arkansas part of the Ozark aquifer was constructed. The Ozark aquifer in northern Arkansas is composed of dolomite, limestone, sandstone, and shale of Upper Cambrian to Middle Devonian age, which dips to the south and southeast away from the St. Francois Mountains of southeastern Missouri. The aquifer is complex, characterized by discrete hydrogeologic units with large variations in permeability. The principal recharge area for the aquifer is in southern and central Missouri and north-central Arkansas where the aquifer is hydraulically connected to the surface.

A potentiometric-surface map of the Ozark aquifer in northern Arkansas for 2010 indicates the maximum measured water-level altitude is 1,174 feet (ft) above National Geodetic Vertical Datum of 1929 (NGVD 29) in Carroll County, and the minimum measured water-level altitude is $120 \mathrm{ft}$ above NGVD 29 in Randolph County. The direction of regional groundwater flow generally is to the south and southeast in the eastern and central part of the study area and to the west, northwest, and north in the western part of the study area, but direction varies most in areas where the unconfined part of the aquifer is hydraulically connected to the surface. In these areas, the flow direction is affected more by local topography (flowing from high altitudes toward stream valleys). The 2010 potentiometric-surface map is very similar to prior maps. Potentiometric-surface differences can be attributed to differences in hydrologic stresses (withdrawals related to changing population, changing dependence on surface water, differences in withdrawals for agricultural uses, or withdrawal conditions just prior to a water-level measurement) or datacollection and map-construction methods (time of year or different numbers and locations of water-level measurements used to construct maps representing different years).
An examination of water-use and population data and hydrograph trends over time provides some insight into changing water levels in the Ozark aquifer. The rapidly increasing population within the study area appears to have some effect on groundwater levels. However, the effect may have been minimized by the development and use of surfacewater distribution infrastructure, suggesting most of the incoming populations are fulfilling their water needs from surface-water sources. The conversion of some users from groundwater to surface water may be allowing water levels in wells to recover (rise) or decline at a slower rate, such as in Benton, Carroll, and Washington Counties. Water levels in wells continue to decline in locations where the users have not converted to surface water, such as in Sharp County.

\section{References Cited}

Adamski, J.C., 1996, Nutrients and pesticides in groundwater of the Ozark Plateaus in Arkansas, Kansas, Missouri, and Oklahoma: U.S. Geological Survey Water-Resources Investigations Report 96-4313, 28 p.

Adamski, J.C., Petersen, J.C., Freiwald, D.A., and Davis, J.V., 1995, Environmental and hydrologic setting of the Ozark Plateaus study unit, Arkansas, Kansas, Missouri, and Oklahoma: U.S. Geological Survey Water-Resources Investigations Report 94-4022, 69 p.

Beaver Water District, 2013, Beaver Water District: accessed April 25, 2013, at http://www.bwdh2o.org/index. php?fuseaction $=$ p0004.\&mod $=11$.

Fenneman, N.M., 1938, Physiography of eastern United States: New York, McGraw-Hill Book Co., Inc., 714 p.

Fenneman, N.M., and Johnson, D.W., 1946, Physical divisions of the United States (map): Washington, D.C., U.S. Geological Survey, scale 1:7,000,000.

Haley, B.R., Glick, E.E., Bush, W.V., Clardy B.F., Stone, C.G., Woodward, M.B., and Zachry, D.L., 1993, Geologic map of Arkansas: Arkansas Geological Survey, 1 pl.

Holland, T.W., 2004, Estimated water use in Arkansas, 2000: U.S. Geological Survey Scientific Investigations Report 2004-5230, $31 \mathrm{p}$.

Holland, T.W., 2007, Water use in Arkansas, 2005: U.S. Geological Survey Scientific Investigations Report 20075241, $32 \mathrm{p}$.

Imes, J.L., 1990, Major geohydrologic units in and adjacent to the Ozark Plateaus Province, Missouri, Arkansas, Kansas, and Oklahoma - Ozark aquifer: U.S. Geological Survey Hydrologic Investigations Atlas HA-711-E, 3 sheets, scale 1:750,000. 
Imes, J.L., and Emmett, L.F., 1994, Geohydrology of the Ozark Plateaus aquifer system in parts of Missouri, Arkansas, Oklahoma, and Kansas: U.S. Geological Survey Professional Paper 1414-D, 127 p.

Imes, J.L., and Smith, B.J., 1990, Areal extent, stratigraphic relation, and geohydrologic properties of regional geohydrologic units, Missouri: U.S. Geological Survey Hydrologic Investigations Atlas HA-711-I, 3 sheets, scale $1: 750,000$.

Lamonds, A.G., 1972, Water-resources reconnaissance of the Ozark Plateaus Province, northern Arkansas: U.S. Geological Survey Hydrologic Investigations Atlas HA-383, 2 sheets, scale 1:500,000.

McCuen, R.A., 1985, Statistical methods for engineers: Englewood Cliffs, New Jersey, Prentice-Hall Inc., 439 p.

Mesko, T.O., and Imes, J.L., 1995, Discharge of ground water along the Ozark escarpment in southeastern Missouri and northeastern Arkansas: U.S. Geological Survey WaterResources Investigations Report 95-4103, 12 p.

Pugh, A.L., 1998, Potentiometric surface of the Ozark aquifer in northern Arkansas, 1995: U.S. Geological Survey WaterResources Investigation Report 98-4000, 7 p.
Pugh, A.L., 2008, Potentiometric surface of the Ozark aquifer in northern Arkansas, 2007: U.S. Geological Survey Scientific Investigations Report 2008-5137, 16 p.

Renken, R.A., 1998, Ground water atlas of the United States, segment 5-Arkansas, Louisiana, Mississippi: U.S. Geological Survey Hydrologic Investigations Atlas 730-F, $28 \mathrm{p}$.

Schrader, T.P., 2001, Potentiometric surface of the Ozark aquifer in northern Arkansas, 2001: U.S. Geological Survey Water-Resources Investigation Report 01-4233, 11 p.

Schrader, T.P., 2005, Potentiometric surface of the Ozark aquifer in northern Arkansas, 2004: U.S. Geological Survey Water-Resources Investigation Report 2005-5208, $10 \mathrm{p}$.

U.S. Census Bureau, 2013, State \& county quickfacts: U.S. Census Bureau, accessed March 13, 2013, at http://quickfacts.census.gov/qfd/states/05000.html.

U.S. Geological Survey, 1990, State of Arkansas (topographic): U.S. Geological Survey Map Publication 34092-E1-ST-500, scale 1:500,000, 1 sheet. 


\section{这}

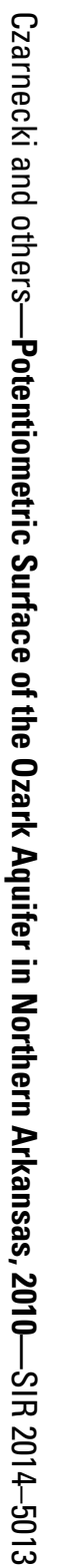

ISSN 2328-0328 (online) 